Original Research Article

\title{
Study of prescription patterns of antihypertensive agents in preeclampsia patients: Central India study
}

\author{
Shreya Shekhar ${ }^{1}$, Tanaji R. Shende ${ }^{1 *}$, A. S. Borkar ${ }^{1}$, Riyaz Siddiqui ${ }^{1}$, Sulabha A. Joshi ${ }^{2}$
}

${ }^{1}$ Department of Pharmacology,

${ }^{2}$ Department of Obstetrics and Gynaecology, NKP Salve Institute of Medical Sciences, Nagpur, Maharashtra, India

Received: 24 September 2018 Accepted: 29 January 2019

\section{*Correspondence to: \\ Dr. Tanaji R. Shende, \\ Email: tanaji.shende@ rediffmail.com}

Copyright: (C) the author(s), publisher and licensee Medip Academy. This is an openaccess article distributed under the terms of the Creative Commons Attribution NonCommercial License, which permits unrestricted noncommercial use, distribution, and reproduction in any medium, provided the original work is properly cited.

\begin{abstract}
Background: The main objective of this study was to evaluate prescription patterns of antihypertensives in preeclampsia patients at a tertiary care hospital in Central India.

Methods: The study belongs to retrospective observational type. he study was conducted by department of Pharmacology in association of department of Obstetrics \& Gynaecology department at Nkp Salve Institute of Medical Sciences \& Research Centre, Lata Mangeshkar Hospital, Nagpur. Permission from Institute Ethics Committee was taken for studying the prescribing patterns of drugs. The study was conducted for a period of 6 months. Inclusion and Exclusion criteria were added.

Results: The maximum number patients seen in age groups $36-41$ (28.6\%). The main drug prescribed in our study was Labetalol followed by methyldopa. In our study most of the patients were of moderate and mild type corresponding to $48 \%$ and $32 \%$ respectively and only $20 \%$ of patients belong to severe cases. In our study highest number of patients was seen in second gravida i.e. $33.33 \%$.

Conclusions: Labetalol was the most common anti hypertensive prescribed in pre eclampsia patients. Rationale prescribing of drugs were done.
\end{abstract}

Keywords: Antihypertensives, Hypertension, Preeclampsia

\section{INTRODUCTION}

Antihypertensives in pregnancy are routinely prescribed to decrease the risk of progression to severe hypertension (systolic blood pressure of $\geq 160 \mathrm{mmHg}$ ). ${ }^{1}$

Hypertensive disorders accounts one of the most common disorders in pregnancy. They are amongst the major cause of maternal and perinatal morbidity and mortality. ${ }^{2}$ Rational prescription patterns are defined as patients receiving medications according to their medical condition, in doses that meet their requirements, for an adequate period of time, and at affordable cost to them and the society. Appropriate prescribing has a positive implication on medication adherence and disease improvement. ${ }^{3}$ Irrational prescription pattern (IPP) occurs when the antihypertensive drug is given at inappropriate dose, frequency, and duration

Preeclampsia defined as a multisystem disorder characterized by new onset of hypertension i.e. systolic blood pressure (SBP) $>140 \mathrm{mmHg}$ and/or diastolic blood pressure (DBP) $>90 \mathrm{mmHg}$ ) arising after 20 weeks of gestation in a previously normotensive woman. Recently, the American College of Obstetricians and Gynecologists has stated that proteinuria is no longer required for the diagnosis of preeclampsia. ${ }^{4}$ 
There is increased risk of premature delivery, intrauterine foetal death, abruption placentae, growth retardation in hypertensive pregnant mothers, moreover there is also chances for increased vascular injury with thrombotic microangioplasty, coagulopathy, cerebrovascular haemorrhage and multiorgan injury. ${ }^{5}$ Pre-eclampsia is more common among women likely to have a large placenta (such as those with multiple pregnancy) and among women with medical conditions associated with microvascular diseases.

\section{Hypertension in pregnancy is of following major types ${ }^{6}$}

Chronic hypertension: Blood pressure (BP) $\geq 140 / 90 \mathrm{mmHg}$ is diagnosed before pregnancy in first 20 weeks of gestation or persists 42 days after delivery.

Gestational hypertension: Blood pressure $\geq 140 / 90 \mathrm{mmHg}$ established after 20 weeks of gestation and not associated with proteinuria.

Preeclampsia-eclampsia: Hypertension, proteinuria ( $\geq 0.3 \mathrm{~g} / 24$ hours) and edema after 20th week of gestation. Eclampsia is defined as appearance of generalized convulsions associated with signs of pre-eclampsia, or their occurrence within 7 days of parturition and not caused by epilepsy or other convulsive disorder. ${ }^{7}$

The aim of the present study was to study prescription pattern of antihypertensive drugs in preeclampsia patients. Many studies have been done in this field. We have undertaken this study to find prescription patterns of antihypertensives used in preeclampsia in our tertiary care hospital.

\section{METHODS}

A retrospective observational study was conducted by Department of Pharmacology in collaboration with the Department of Obstetrics in NKP Salve Institute of Medical Sciences, Nagpur after taking permission from the Institutional Ethics Committee. Hypertension is defined and staged according to the guidelines of the seventh report of the Joint National committee on prevention, detection, evaluation, and treatment of high blood pressure. ${ }^{8}$ The case record sheets of preeclampsia patients on outpatient department basis within 6 months were reviewed. The total number of drugs prescribed, with dosage, frequency, duration was recorded. A total of 150 case records were studied. Pregnant women diagnosed with hypertension in Obstetrics and gynaecology department and pregnant women aged more than 18 years are included in the study. Patients with comorbidities are also included.

\section{Inclusion criteria}

Inclusion criteria were patients diagnosed with preeclampsia aged more than 18 years included in the study; pregnant women with comorbidities also included.

\section{Exclusion criteria}

Exclusion criteria were the patients who does not come under obstetrics \& gynaecology department; incomplete medical records; psychiatric patients.

\section{Study duration}

The study was conducted from February to July 2018 for period of 6 months at NKP Salve Institute of Medical Sciences and Research Centre, Nagpur. During this period 150 cases of preeclampsia were reviewed.

\section{RESULTS}

The case records of total 150 pregnant females diagnosed with pre eclampsia were reviewed. In our study highest number of the cases were observed in age groups of 36-41 years contributing to $28.66 \%$ (43 cases) followed by 40 cases $(26.66 \%)$ seen in age groups of $18-23$ years. It was found that in our study Labetalol was most common drug given to 75 preeclampsia patients followed by methyldopa given in 42 patients, other drugs used were nifedipine (14\%), amlodipine (4\%) and clinidipine (2\%) and magnesium sulphate in $(2 \%)$ of patients. $33.33 \%$ patients belonging to second gravida constitute the majority of patients i.e. 50 patients while $30 \%$ belong to third gravida i.e. 45. Co morbidities found in our study corresponds to gestational diabetes as major comorbidity associated with hypertension in preeclampsia patients contributing $58 \%$ in our study followed by gestational hypothyroidism (36\%), chronic kidney disease (5\%).

Table 1: Demographic distribution of patients.

\begin{tabular}{|llll|}
\hline $\begin{array}{l}\text { Serial } \\
\text { no. }\end{array}$ & $\begin{array}{l}\text { Age groups } \\
\text { (years) }\end{array}$ & $\begin{array}{l}\text { Number of } \\
\text { patients }\end{array}$ & $\begin{array}{l}\text { Percentage } \\
(\%)\end{array}$ \\
\hline 1 & $18-23$ & 40 & 26.66 \\
\hline 2 & $24-29$ & 18 & 12 \\
\hline 3 & $30-35$ & 38 & 25.33 \\
\hline 4 & $36-41$ & 43 & 28.66 \\
\hline 5 & $42-47$ & 11 & 7.33 \\
\hline Total & & 150 & 100 \\
\hline
\end{tabular}

Table 1 shows demographic distribution of patients, the mean age groups was of 30-35 corresponding to $25.33 \%$.

Table 2: Antihypertensives used.

\begin{tabular}{|llll|}
\hline Sl.no & $\begin{array}{l}\text { Antihypertensives } \\
\text { drugs }\end{array}$ & $\begin{array}{l}\text { No. of } \\
\text { patients }\end{array}$ & $\begin{array}{l}\text { Percentage } \\
(\%)\end{array}$ \\
\hline 1 & Labetalol & 75 & 50 \\
\hline 2 & Methyldopa & 42 & 28 \\
\hline 3 & Nifedipine & 21 & 14 \\
\hline 4 & Amlodipine & 6 & 4 \\
\hline 5 & Clinidipine & 3 & 2 \\
\hline 6 & $\begin{array}{l}\text { Magnesium } \\
\text { sulphate }\end{array}$ & 3 & 2 \\
\hline
\end{tabular}


According to Table 2, most commonly used drug in our hospital was Labetalol given to 75 patients followed by Methyldopa given to 42 patients followed by other drugs like nifedipine, amlodipine.

Table 3: Gravida wise distribution of patients.

\begin{tabular}{|llll|}
\hline Sl.no & Gravida & $\begin{array}{l}\text { No. of } \\
\text { patients }\end{array}$ & $\begin{array}{l}\text { Percentage } \\
(\%)\end{array}$ \\
\hline 1 & Primigravida & 32 & 21.33 \\
\hline 2 & Second gravida & 50 & 33.33 \\
\hline 3 & Third gravida & 45 & 30 \\
\hline 4 & Fourth gravida & 06 & 4 \\
\hline 5 & Multi gravida & 17 & 11.33 \\
\hline Total & & 150 & 100 \\
\hline
\end{tabular}

Table 3 shows gravida wise distribution of patients in our hospital, $33.33 \%$ patients belonging to second gravida constitute the majority of patients i.e. 50 patients while $30 \%$ belong to third gravida.

According to Table 4, most of the patients were of moderate and mild type corresponding to $48 \%$ and $32 \%$ respectively and only $20 \%$ of patients belong to severe cases.

Table 4: Blood pressure range of patients before administration of drugs.

\begin{tabular}{|lllll|}
\hline Sl.no & $\begin{array}{l}\text { Blood } \\
\text { pressure } \\
\text { range }\end{array}$ & $\begin{array}{l}\text { Blood } \\
\text { pressure }\end{array}$ & $\begin{array}{l}\text { No. of } \\
\text { patients }\end{array}$ & $\%$ \\
\hline 1 & Mild & $\begin{array}{l}140-159 / \\
90-99\end{array}$ & 48 & 32 \\
\hline 2 & Moderate & $\begin{array}{l}160-179 / \\
100-109\end{array}$ & 72 & 48 \\
\hline 3 & Severe & $>180 />100$ & 30 & 20 \\
\hline Total & & & 150 & 100 \\
\hline
\end{tabular}

Table 5: Co-morbidities.

\begin{tabular}{|llll|}
\hline Sl.no & $\begin{array}{l}\text { Co-morbidity with } \\
\text { hypertension }\end{array}$ & $\begin{array}{l}\text { No. of } \\
\text { patients }\end{array}$ & $\%$ \\
\hline 1 & $\begin{array}{l}\text { Gestational diabetes } \\
\text { (GDM) }\end{array}$ & 57 & 58.16 \\
\hline 2 & $\begin{array}{l}\text { Gestational } \\
\text { hypothyroidism }\end{array}$ & 36 & 36.73 \\
\hline 3 & $\begin{array}{l}\text { Chronic kidney disease } \\
\text { (CKD) }\end{array}$ & 5 & 5.1 \\
\hline Total & & 98 & \\
\hline
\end{tabular}

Table 5 indicates gestational diabetes as major comorbidity associated with hypertension in preeclampsia patients contributing $58 \%$ in our study followed by gestational hypothyroidism (36\%), chronic kidney disease $(5 \%)$.

\section{DISCUSSION}

Hypertension in pregnancy is considered to be a major worldwide health problem leading to an increased risk of Perinatal and maternal mortality. ${ }^{9}$ Preeclampsia is more frequent in patients younger than 21 years of age and in older than $35 .{ }^{10}$ In our study 40 patients lie in age group of 18-23 years and 43 patients lie in age group of 36-41 years. The main antihypertensive prescribed to the patients in our study was Labetalol which given to 75 patients followed by Methyldopa given to 42 patients. In our study the most common comorbidity associated with hypertension was gestational diabetes followed by gestational hypothyroidism. There is an increased chance of hypertension in young primigravidae under 20 years and all patients over 30 years. ${ }^{11}$

According to Sajith et al, a prospective study was conducted at pune tertiary care hospital for a period of one year in which aim was to determine frequency and distribution of different types of hypertensive disorders in pregnancy. Pre eclampsia was more seen in age groups of 18-22 years in above study, in our study also most of the pre eclampsia patients belong to age group 18-23 years that is 40 patients and also 43 patients in age groups $36-$ 41 which is similar to above study. ${ }^{12}$

In Anju et al, the study was conducted over a period of 6 months including 150 patients diagnosed with hypertension. In this study main drug used was methyldopa which is second most drug prescribed in our study. ${ }^{13}$

Similarly in a study by Cvijic et al, Methyldopa was most commonly prescribed antihypertensive drugs in $27.8 \%$ of patients. ${ }^{14}$ In Anju et al study the gravidawise distribution of patients is mostly seen in second gravida patients accounting to $34 \% .{ }^{13}$ In our study similarly to above study contributes $33.33 \%$ to second gravida patients while $30 \%$ seen in third gravida.

In our study the most common drug given to preeclampsia patients was Labetalol which corresponds similar to study done by Sajith et al in which Labetalol is given in mild and severe cases of pre eclampsia. In our study most of the cases of preeclampsia were of mild and moderate type accounting to $80 \%$ of total cases.

According to a trial done at Pune tertiary care hospital in 2013 , the purpose of the trial was to study the role of labetalol (oral) as a first-line drug for hypertensive disorders in pregnancy in an open prospective trial(15)and the study concluded that labetalol has more benefits over methyldopa as it doesnot causes haemolysis, thrombocytopenia, constipation, galactorrhea, postpartum depression and altered sleep patternAlpha-methyldopa accumulates in renal failure, which can sometimes complicate pre-eclampsia. ${ }^{15}$ In our study also labetalol is used as first line anti hypertensive in preeclampsia patients given to 75 patients corresponding to $50 \%$ of 
total preeclampsia patients and methyldopa given to $28 \%$ of the patients.

In a study Yamakanamardi et al, retrospective study was conducted in hypertensive pregnant women for a period of one year, prescribing pattern of antihypertensive drugs were studied, according to above study most common comorbid illness found was hypothyroidism followed by anaemia and diabetes. In our study gestational diabetes was seen most commonly comorbidity associated with hypertension seen in 57 patients out of 98 patients contributing to $58.16 \%$ followed by hypothyroidism in $36.73 \%$ patients. $^{5}$

Calcium channel blockers should not be given as first line drugs because they can inhibit the contractions of uterus. ${ }^{7}$

\section{CONCLUSION}

Hypertension in pregnancy has become one of the major alarming situation in a pregnant woman's life. Our study concluded that Labetalol is commonly used for preeclampsia in tertiary care hospital due to its benefits followed by Methyldopa as methyldopa is considered safe in pregnancy. To conclude our study gave an overall idea of prescribing pattern of antihypertensive drugs and we should focus more on rationale prescribing of drugs. In our study most of the preeclampsia patients belong to moderate category of hypertension. More similar studies should be done so that rationale prescribing patterns of antihypertensives will be more effectively practiced and result will lead to a healthy mother. Promotion of rationale prescribing of drugs should be done by cme's, orientation programmes, lectures.

Funding: No funding sources Conflict of interest: None declared

Ethical approval: The study was approved by the Institutional Ethics Committee

\section{REFERENCES}

1. Redman CW. Hypertension in pregnancy:the NICE guidelines. Heart. 2011;97:1967-9.

2. Roberts J, Pearson G, Cutler J, Lindheimer M. Summary of the NHLBI working group on research on hypertension during pregnancy. Hypertens. 2003;41(3):437-45.

3. Shrank WH, Hoang T, Ettner SL, et al. The implications of choice:prescribing generic or preferred pharmaceuticals improves medication adherence for chronic conditions. Arch Intern Med. 2006;166(3):332-7.

4. Lambert G, Brichant JF, Hartstein G, Bonhomme V, Dewandre PY. Preeclampsia: an update. Acta Anaesthesiol Belg. 2014;65(4):137-49.
5. Yamakanamardi S, Anuradha HV, Sujani BK, Shivamurthy MC. Analysis of prescribing pattern of antihypertensive drugs during pregnancy and neonatal outcome in a tertiary care centre. Int J Basic Clin Pharmacol. 2016;5:718-21.

6. Folic M, Folic N, Varjacic M, Jakovljevic M, Jankovic S. Antihypertensive drug therapy for hypertensive disorders in pregnancy. Acta Medica Medianae. 2008;47(3):67-71

7. T Naveen Kumar, Tadvi NA, Kaul R. Prescription pattern of drugs in pregnancy induced hypertension in a tertiary care hospital. Int J Basic Clin Pharmacol 2013;2:783-7.

8. JNC 7 express. The seventh report of the Joint National committee on prevention, detection, evaluation and treatment of high blood pressure. Available at: http://www.nhlbi.nih.gov/guidelines/ hypertension/ex press.pdf. Accessed on 28 January 2016.

9. Kauntiz AM, Hughes JM, Grimes DH, Smith JC, Rochat RW, Kaffrissen ME. Causes of maternal mortality in the United States of America. J Obstetr Gynecol. 1985;65:605-12.

10. Sheraz S, Shahzad S, Boota M. Eclampsia. Prof Med J. 2006;13(1):27-31.

11. Zibaeenazhad MJ, M Ghodsi P Arab, Gholzom N. the prevalence of hypertensive disorders of pregnancy in Shiraz, Southern Iran; Iranian Cardiovascular Res J. 2010;4:169-72.

12. Sajith M, Nimbargi V, Modi A, Sumariya R, Pawar A. Incidence of pregnancy induced hypertension and prescription pattern of antihypertensive drugs in pregnancy. Int J Pharma Sci Res. 2014;23:4.

13. Ramkumar K, Anju AS, Kandel P, Vishwanath BA, Kumar P. A study on prescribing pattern of antihypertensive drugs during pregnancy in tertiary care hospital, banglore. Indo Am J Pharm Res. 2016;6;09:6537-46.

14. Gersak K, Cvijic M, Cerar LK. Angiotensin II receptor blockers in pregnancy:a report of five cases. Reprod Toxicol. 2009;28(1):109-12.

15. Girija SD. Labetalol-An emerging first line drug for pregnancy induced hypertension. Indian J Clin Prac. 2013;23:640-1.

16. Abalos E, Duley L, Steyn DW, Henderson-smart DJ. Antihypertensive drug therapy to mild to moderate hypertension during pregnancy. Cochrane Database Syst Rev. 2003;1:CD002252.

Cite this article as: Shekhar S, Shende TR, Borkar AS, Siddiqui R, Joshi SA. Study of prescription patterns of antihypertensive agents in preeclampsia patients: Central India study. Int J Basic Clin Pharmacol 2019;8:478-81. 